\title{
The impacts of future climate change and sulphur emission reductions on acidification recovery at Plastic Lake, Ontario
}

\author{
J. Aherne ${ }^{1}$, M. N. Futter ${ }^{2}$, and P. J. Dillon ${ }^{1}$ \\ ${ }^{1}$ Environmental and Resource Studies, Trent University, Peterborough, Canada \\ ${ }^{2}$ Watershed Ecosystems Graduate Program, Trent University, Peterborough, Canada
}

Received: 8 December 2006 - Published in Hydrol. Earth Syst. Sci. Discuss.: 11 September 2007

Revised: 2 December 2007 - Accepted: 5 February 2008 - Published: 5 March 2008

\begin{abstract}
Climate-induced drought events have a significant influence on sulphate export from forested catchments in central Ontario, subsequently delaying the recovery of surface waters from acidification. In the current study, a model chain that employed a statistical downscaling model, a hydrological model and two hydrochemical models was used to forecast the chemical recovery of Plastic Lake sub-catchment 1 (PC1) from acidification under proposed deposition reductions and the A2 emission scenario of the Intergovernmental Panel on Climate Change. Any predicted recovery in stream acid neutralising capacity and $\mathrm{pH}$ owing to deposition reductions were clearly offset by large acid effluxes from climateinduced drought events. By 2100, ANC is predicted to show large variations ranging between 10 and $-30 \mu \mathrm{mol}_{c} \mathrm{~L}^{-1}$. Similarly, predicted $\mathrm{pH}$ in 2100 is lower $(>0.05$ of a $\mathrm{pH}$ unit) than the value simulated for $2000(\mathrm{pH} 4.35)$. Despite emission reductions, the future scenario paints a bleak picture of reacidification at $\mathrm{PC} 1$ to levels commensurate with those of the late 1970s. The principal process behind this reacidification is the oxidation of previously stored (reduced) sulphur compounds in wetlands during periods of low-flow (or drought), with subsequent efflux of sulphate upon rewetting. Simulated catchment runoff under the A2 emissions scenario predictes increased intensity and frequency of lowflow events from approximately 2030 onwards. The Integrated Catchments model for Carbon indicated that stream DOC concentrations at $\mathrm{PC} 1$ will also increase under the future climate scenario, with temperature being the principal driver. Despite the predicted (significant) increase in DOC, $\mathrm{pH}$ is not predicted to further decline (beyond the climateinduced oxidation scenario), instead $\mathrm{pH}$ shows greater variability throughout the simulation. As echoed by many recent studies, hydrochemical models and model frameworks need to incorporate the drivers and mechanisms (at appropri-
\end{abstract}

Correspondence to: J. Aherne

(julian.aherne@ucd.ie) ate time-scales) that affect the key biogeochemical processes to reliably predict the impacts of climate change.

\section{Introduction}

Since the 1980s, sulphur (S) emission control programs in North America have resulted in major declines (approximately $40 \%)$ in sulphate $\left(\mathrm{SO}_{4}^{2-}\right)$ deposition over southcentral Ontario, Canada. As a consequence, $\mathrm{SO}_{4}^{2-}$ concentrations in headwater lakes and their inflows have decreased; however, concomitant chemical recovery of alkalinity and pH has been limited (Jeffries et al., 1995; McNicol et al., 1998; Stoddard et al., 1999). In Ontario, climate-induced drought events have been identified as a major cause of the delayed recovery (Dillon et al., 1997; Jeffries et al., 2002; Eimers and Dillon, 2002; Laudon et al., 2004). A number of studies at Plastic Lake in south-central Ontario have clearly demonstrated that acidity of a stream draining a wetland portion of the catchment increased substantially after periods of drought (Dillon and LaZerte, 1992; LaZerte, 1993; Devito and Hill, 1999; Eimers et al., 2004). The Model of Acidification of Groundwater in Catchments (MAGIC: Cosby et al., 1985, 2001) has been successful in reproducing the observed trends at Plastic Lake and supports the hypothesis that wetland redox processes can explain much of the inter-annual variation in $\mathrm{SO}_{4}^{2-}, \mathrm{pH}$ and base cation stream concentrations (Aherne et al., 2004). The redox processes (triggered by low-flow events) incorporated in the wetland compartment in MAGIC were essential to reproducing the observed chemistry. This model was further used to quantify the potential influence of climate-induced drought events on acidification recovery under proposed future emission reductions (Aherne et al., 2006). However, the study noted that reliable forecasts of recovery from acidification require climate scenarios downscaled from global climate models and high-resolution scenarios for catchment discharge.

Published by Copernicus Publications on behalf of the European Geosciences Union. 


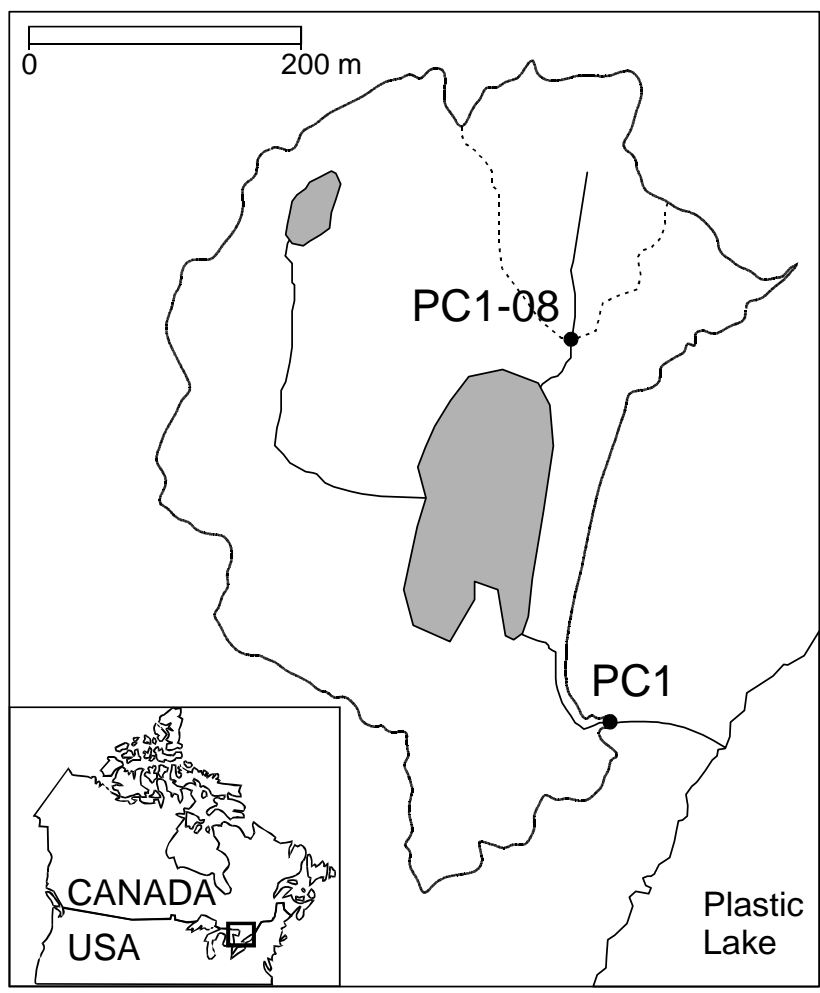

Fig. 1. Map of Plastic Lake gauged catchment No. 1 (PC1, 23.3 ha) showing the gauged sub-catchment (PC1-08, 3.5 ha; broken line) and wetland areas (principal swamp is 2.2 ha; grey). Filled circles indicate gauged catchment outlets (sampling stations).

In addition to redox processes, there are a number of other factors that can influence the extent of chemical recovery from acidification. In particular, the confounding influence of increasing dissolved organic carbon (DOC) concentrations has recently received considerable attention (Skjelkvåle et al., 2003, 2005; Worrall et al., 2004; Evans et al., 2006; Roulet and Moore, 2006). It has been hypothesised that factors related to climate change may be (somewhat) responsible for the increases in DOC (Freeman et al., 2001, 2004; Hejzlar et al., 2003; Evans et al., 2005), which have been observed across Europe and eastern North America during the past 10-20 years (Stoddard et al., 2003). Recently MAGIC was used to evaluate the effect of climate change on the recovery of soil and surface water from acidification (Wright et al., 2006). The approach employed a simple sensitivity analyses at 14 intensively studied sites in Europe and eastern North America. The analyses suggested that the direct influence of climate change (temperature, precipitation and runoff) had very little impact on model simulations. However, Wright et al. (2006) suggested that the modelling of recovery from acidification should take into account possible concurrent climate changes (e.g., organic matter decomposition in soils and nitrogen retention) and focus especially on the climate-induced changes in organic acids.
In this paper a sophisticated model chain framework is used in conjunction with MAGIC to forecast the impacts of future climate change and S deposition reductions on the chemical recovery of the Plastic Lake catchment from acidification. The approach is similar to previous linked model systems that use hydrochemical effects models (Forsius et al., 1997; Kaste et al., 2006). The ultimate goal of the model chain was to provide high-resolution inputs of climate and catchment discharge to drive aquatic DOC inputs and redox processes within MAGIC. The National Centre for Environmental Prediction (NCEP) re-analysis data set (Kalnay et al., 1996) were used in conjunction with outputs from the HadCM3 (Hadley Centre, UK) general circulation models (GCM) to generate a long-term (1960-2100) climate change sequence. The data were downscaled to the study site using the Statistical Downscaling Model (SDSM: Wilby et al., 2002) and further used to generate long-term site-specific sequences for catchment runoff and DOC using the Hydrologiska Byråns Vattenbalansavdelning (HBV: Bergström, 1976) model and the Integrated Catchments model for Carbon (INCA-C: Futter et al., 2007). These data, combined with $\mathrm{SO}_{4}^{2-}$ deposition, were the principal driving inputs to MAGIC. The deposition forecast was derived from recently proposed $\mathrm{S}$ emission reduction estimates using the Acid Deposition and Oxidant Model (ADOM; WxPrime, 2004).

\section{Methods}

\subsection{Study site}

Plastic Lake (32.1 ha headwater lake) is located on the Precambrian Shield in Haliburton County, south-central Ontario $\left(45^{\circ} 11^{\prime} \mathrm{N}, 78^{\circ} 50^{\prime} \mathrm{W}\right)$, in an area that has received substantial levels of acid deposition for decades (Dillon et al., 1987). The Plastic Lake catchment $(96.5 \mathrm{ha})$ is drained by seven small streams, six of which are ephemeral. The largest of the sub-catchments (PC1, 23.3 ha) flows year-round except in very dry years (Fig. 1). Five of the seven sub-catchments, including PC1, drain wetlands. The upland soils of PC1 (and it's gauged sub-catchment PC1-08, 3.5 ha: Fig. 1) are sandy, shallow, humo-ferric or ferro-humic podzols (Lozano, 1987). Quartz, plagioclase, potassium feldspar, and amphibole dominate the parent material of the soil (Kirkwood and Nesbitt, 1991). The PC1 upland forest cover is primarily coniferous, dominated by white pine (Pinus strobus L.), red maple (Acer rubrum L.), eastern hemlock (Tsuga canadensis (L.) Carrière) and red oak (Quercus rubra L.). The wetland (Sphagnum-conifer swamp, $2.2 \mathrm{ha}$ ) soils are humic mesisols dominated by white cedar (Thuja occidentalis $\mathrm{L}$.). The catchment altitude ranges from $380-420 \mathrm{~m}$ a.s.l., annual rainfall averages $\sim 1000 \mathrm{~mm}$ and the mean January and July air temperatures are -9.4 and 18.6 , respectively.

The Plastic Lake catchment has been extensively monitored since the late 1970s and has been previously described 
(bulk precipitation: Dillon et al., 1988; forest throughfall: Neary and Gizyn, 1994; soil: Lozano, 1987; Watmough and Dillon, 2004; forest biomass: Lozano and Parton, 1987; Watmough and Dillon, 2004). Stream discharge and chemistry has been measured for the PC1 sub-catchment since 1979 (PC1-08: 1986-1995). The field, hydrologic, and analytical methods are described in detail elsewhere (OME, 1983; Locke and Scott, 1986; methods have remained unchanged). Meteorology has been measured at the nearby Muskoka airport $\left(44^{\circ} 58^{\prime} \mathrm{N}, 79^{\circ} 18^{\prime} \mathrm{W}\right)$ since the early $1940 \mathrm{~s}$.

\subsection{Future climate and deposition scenarios}

In the current study, future climate (temperature and precipitation) data were derived from the HadCM3 GCM under the A2 emission scenarios of the Intergovernmental Panel on Climate Change (IPCC). The A2 scenario represents a pessimistic future with high emissions of greenhouse gases (Nakićenović et al., 2000), and was chosen under the current study to represent a maximum climate change scenario. The scenario is one of four that have been uniformly chosen under the European Union Euro-Limpacs project: A2 and B2 emission scenarios of the IPCC derived from the HadCM3 and ECHAM4/OPYC3 (Max Planck Institute, Germany) GCMs. The HadCM3 climate was chosen in preference to ECHAM4/OPYC3 for purely pragmatic reasons: availability of data in a format for statistical downscaling.

Sulphate deposition forecasts were derived from recently proposed emission reduction estimates from ADOM (WxPrime, 2004). Unlike previous reduction scenarios (PST2010F: Kaminski, 2002) based on (semi-realistic) regional rollback strategies, the current scenario (NOX3P: WxPrime, 2004) is entirely sectoral based (metal smelters, power plants, transportation, etc.) and includes reductions in nitrogen oxide emissions. The proposed reductions are based on Canada's post-2000 Acid Rain Strategy and the proposed Clear Skies Legislation in the United States. The reductions roughly correspond to a decrease of $40 \%$ for $\mathrm{SO}_{4}^{2-}$ depositions by 2020 from a 1989 baseline, remaining constant thereafter.

\subsection{Model chain framework}

The suite of models employed in the current study have been previously well described (Cosby et al., 1985; Bergström, 1976; Wilby et al., 2002; Futter et al., 2007). Similarly, the application of MAGIC to the Plastic Lake catchment and the calibration of the wetland redox processes within MAGIC have been previously described (Aherne et al., 2004, 2006). Further, the model framework utilised in the current study is similar to previous model chains that have used hydrochemical effects models (Forsius et al., 1997; Kaste et al., 2006). As such, the individual models and the model framework are only briefly described.

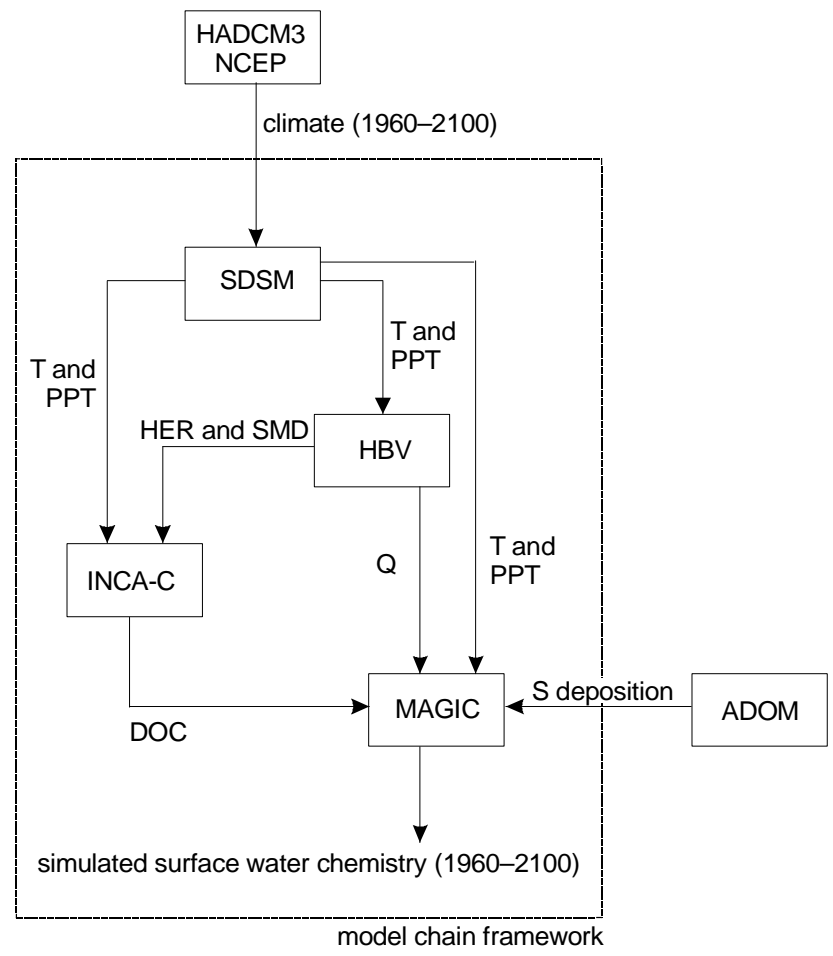

Fig. 2. Flowchart of the model chain framework (dashed box) employed to investigate the impacts of future climate change and sulphur emission reductions on acidification recovery at Plastic Lake, Ontario. The diagram indicates the information flow (temperature (T), precipitation volume (PPT), streamflow discharge $(\mathrm{Q})$, hydrologically effective rainfall, (HER), soil moisture deficit (SMD), dissolved organic carbon (DOC) and sulphate (S) deposition) between the suite of models (Statistical Downscaling Model (SDSM), Hydrologiska Byråns Vattenbalansavdelning (HBV), Integrated Catchments model for Carbon (INCA-C) and the Model of Acidification of Groundwater in Catchments (MAGIC)) employed in the framework. Models not specifically calibrated for use in the current study are external to the model framework (located outside the dashed box): HadCM3 (Hadley Centre, UK) general circulation model (GCM), the National Centre for Environmental Prediction (NCEP) re-analysis data set and the Acid Deposition and Oxidant Model (ADOM).

The model framework consisted of four models: SDSM, HBV, INCA-C and MAGIC (Fig. 2). In brief, SDSM is a statistical downscaling model that facilitates the downscaling of GCM output to individual sites at daily timescales (Wilby et al., 2002). The hydrological model HBV, is a daily time-step, semi-distributed catchment runoff (discharge) model. The model was originally developed in the 1970s at the Swedish Meteorological and Hydrological Institute (Bergström, 1976); the version used in the current study was developed to simulate the effects of climate change on river runoff (Sælthun, 1996). The Integrated Catchments model for Carbon, is a dynamic, daily time-step, semidistributed catchment scale process-based model of DOC 

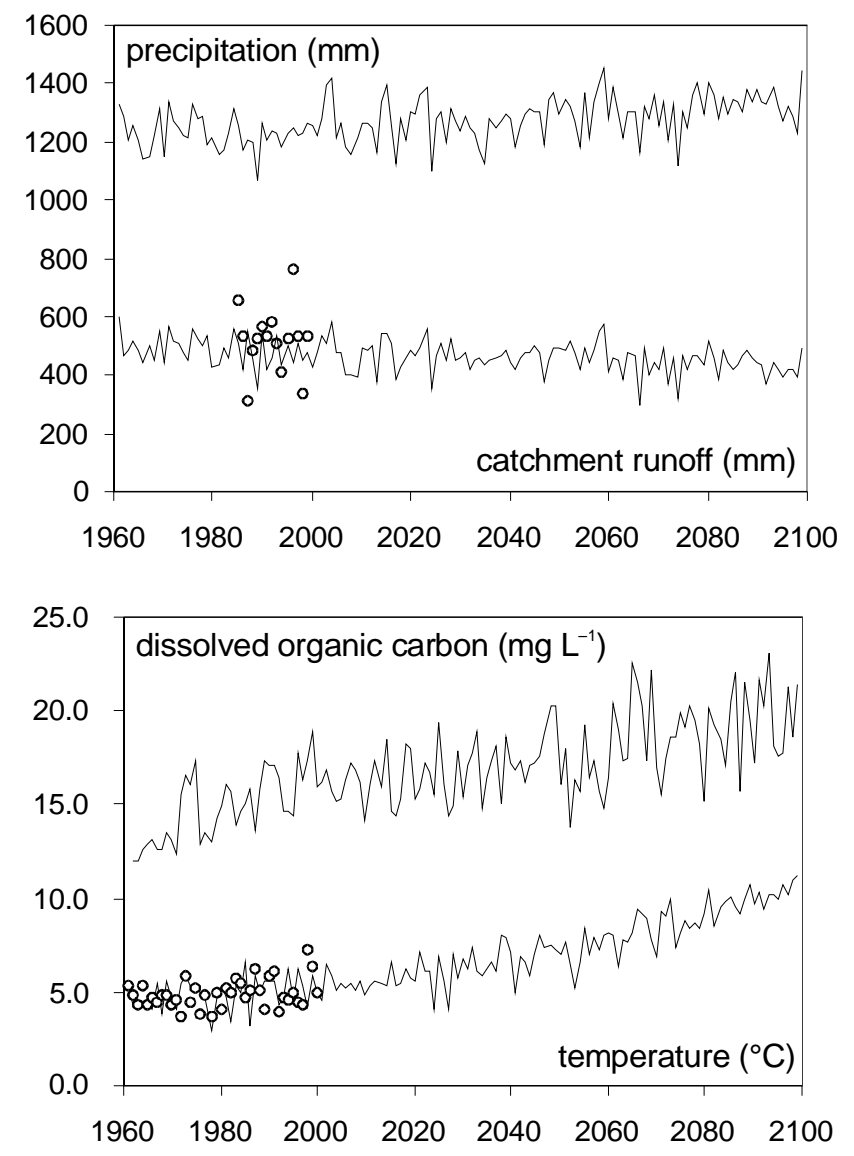

Fig. 3. Annual precipitation and runoff volume (mm: upper panel); annual average temperature $\left({ }^{\circ} \mathrm{C}\right)$ and stream dissolved organic carbon (mg L ${ }^{-1}$ : lower panel) for the period 1960-2100. Observed data for runoff and temperature during the calibration period 19802000 are also shown (open circles).

concentration and flux in streams and rivers. The model was recently developed to investigate the effects of climate on DOC in surface waters (Futter et al., 2007). Finally, MAGIC is a lumped-parameter model of intermediate complexity, developed to predict the long-term effects of acidic deposition on soils and surface water chemistry (Cosby et al., 1985, 2001). The model predicts monthly and annual average concentrations of the major ions for soil solution and surface water chemistry. MAGIC represents the catchment with aggregated, uniform soil compartments, and a surface water compartment that can be either a lake or a stream. It has been in use for $>20$ years and has been applied extensively in North America and Europe (see Appendix I in Cosby et al., 2001). The latest version includes a wetland compartment that incorporates redox processes driven by climateinduced drought events. The four models were not linked or integrated under one unified system, rather outputs from one model were fed or chained to the next model (Fig. 2); as such, the framework did not include any feedbacks between mod- els. Furthermore, all daily time-step outputs were averaged or summed to a monthly time-step for MAGIC. Again, the approach is similar to previous hydrochemical model chains (Forsius et al., 1997; Kaste et al., 2006).

The model chain framework was primarily developed to generate high-resolution climate, runoff and DOC inputs to MAGIC. Firstly, SDSM was used to generate daily temperature and precipitation at Muskoka airport for the period 1960-2100 using the NCEP re-analysis data set (19601990) and outputs from the HadCM3 GCM (A2 scenario: 1990-2100). The downscaled temperature and precipitation were used to generate daily catchment runoff, soil moisture deficit (SMD) and hydrologically effective rainfall (HER) using HBV (Fig. 2). The outputs from HBV were used as inputs to INCA-C to generate daily stream DOC concentrations at PC1 for the period 1960-2100. Daily time-series outputs from these models (SDSM, HBV and INCA-C) of temperature, precipitation, runoff and DOC were aggregated to monthly resolution and utilised in conjunction with proposed $S$ deposition reductions to simulated surface water chemistry at PC1 using MAGIC (Fig. 2).

\subsection{Model calibration and simulation}

Under SDSM, the NCEP re-analysis data set (1960-1990) was used to develop statistical models for observed daily temperature and precipitation at Muskoka airport. To provide better correspondence between simulated and observed meteorology, SDSM assigns a stochastic residual to the deterministic predictor-predictand relationships (Wilby et al., 2002). The calibrated model was used to generate ensembles (100 individual time-series) of daily temperature and precipitation at Muskoka airport for the period 1960-2100 using the NCEP re-analysis data set (1960-1990) and outputs from the HadCM3 GCM (A2 scenario: 1990-2100). The ensembles were generated to provide a more robust estimated of downscaled temperature and precipitation; however, only the median time-series were used as inputs to MAGIC. In general, statistical downscaling models are more successful at reproducing temperature compared with precipitation. In the current study, simulated and observed temperature show reasonable correspondence (Fig. 3), whereas simulated precipitation was approximately $15 \%$ higher than observed (not shown). The mis-match between observed and simulated precipitation is primarily due to imprecise and highly variable rainfall forecasts from the current generation of GCMs.

The downscaled temperature and precipitation were used to generate ensembles (based on 250 individual time-series derived from random combinations of the temperature and precipitation data sets) of daily catchment runoff, SMD and HER using HBV, which was calibrated to PC1 using observed daily temperature, precipitation and streamflow (1980-2000). The model performance was evaluated using the Nash-Sutcliffe efficiency criterion, with 1.0 corresponding to perfect fit (Nash and Sutcliffe, 1970). Acceptable 
values for hydrological model calibrations are normally within the range of $0.6-0.9$; a value of 0.71 was obtained in the current study. Observed and simulated runoff show reasonable correspondance (Fig. 3). The outputs from HBV (HER and SMD) were utilised in conjunction with observed DOC and streamflow at PC1 (1980-2000) to calibrate INCA$\mathrm{C}$ and further generate an ensemble (250 time-series) of daily stream DOC concentrations at PC1 for the period 19602100. A Nash-Sutcliffe efficiency criterion of 0.23 was obtained for the calibration of INCA-C to PC1. Downscaled climate (temperature and precipitation) were used in the calibration process resulting in the apparent low efficiency; however, the values are within the range for previously reported INCA-C calibrations (0.0-0.6: Futter et al., 2007).

The application of MAGIC to the Plastic Lake catchment and the calibration of the wetland redox processes within MAGIC have been previously described (Aherne et al., 2004, 2006). The calibration was carried out in two stages. The first stage focused only on the PC1-08 sub-catchment (which excluded the wetland component) using observed inputs and outputs for the period 1986-1995. The second calibration focused on the entire PC1 catchment (including the wetland). Model performance was evaluated using Normalised Mean Absolute Error (NMAE), which ranges between zero and one with zero indicating absolute agreement between predicted and observed (Janssen and Heuberger, 1995). Simulated PC1 stream concentrations were calibrated by adjusting $\mathrm{S}$ reduction and oxidation parameters, with reduction only occurring when discharge was greater than $5 \mathrm{~cm} \mathrm{mo}^{-1}$ (calibrated threshold) and oxidation only occurring when discharge was less than $5 \mathrm{~cm} \mathrm{mo}^{-1}$. The "oxidation threshold" was only implemented during the summer months (June-October). The calibrated threshold in the current study is higher than previously reported values (Aherne et al., 2004, 2006), as HBV modelled runoff did not adequately simulate low-flow events. An NMAE of $0.20,0.16$ and 0.10 were obtained for $\mathrm{SO}_{4}^{2-}$, base cations (calcium + magnesium + sodium + potassium) and $\mathrm{pH}$ during the calibration period (1980-2000). Further details are given by Aherne et al. (2006).

The model framework was employed to investigate the influence of future climate and S deposition reductions on the recovery of PC1 from acidification. Daily time-series outputs from SDSM, HBV and INCA-C for temperature, precipitation, runoff and DOC were aggregated to monthly resolution (temperature and DOC were averaged; precipitation and runoff were summed) as inputs to MAGIC (Fig. 3). Only the median of the climate, runoff and DOC ensembles were used as inputs to MAGIC. The study utilised three simulation scenarios (Base, Redox and DOC); all three scenarios commonly incorporated the direct influence of climate (temperature, precipitation and runoff) and $\mathrm{S}$ deposition reductions (see Table 1). However, the "Base scenario" excluded the influence of redox events (the "redox switch" was turned off in MAGIC). The "Redox scenario" included the influence of redox events ("redox switch" turned on), and
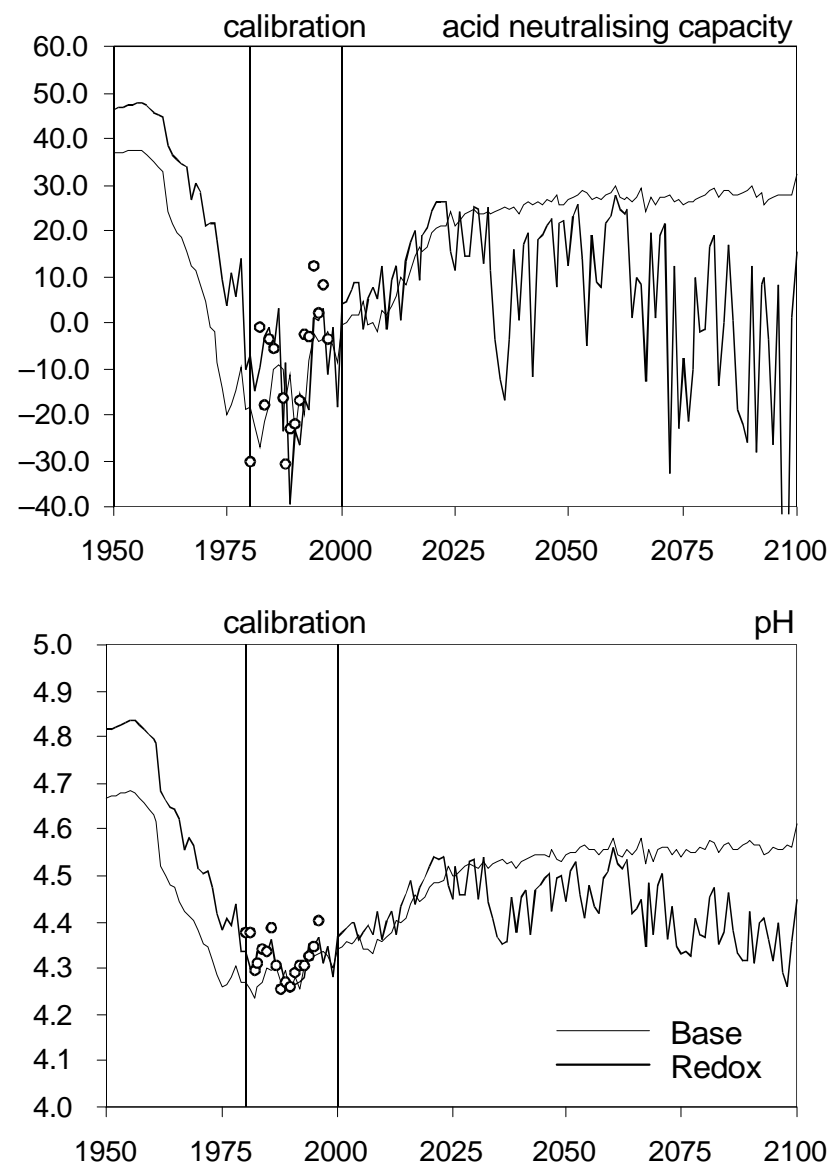

Fig. 4. Simulated acid neutralising capacity $\left(\mu \mathrm{mol}_{c} \mathrm{~L}^{-1}\right.$ : upper panel) and $\mathrm{pH}$ (lower panel) under the base scenario (thin line) and redox scenario (thick line) for the period 1960-2100. The calibration period (1980-2000) and the observed data (open circles) are also shown.

finally the "DOC scenario" investigated the potential influence of future changes in surface water DOC concentrations on the acid status of PC1. Future DOC stream concentrations were assumed to directly follow the change given by INCA-C ("delta-change method"). The DOC scenario was superimposed upon the redox scenario.

\section{Results and discussions}
3.1 Influence of emission reductions and climate on recov- ery

Future recovery patterns (until the year 2100) were evaluated using two key indicators: acid neutralising capacity (ANC defined as the sum of base cations minus the sum of strong acid anions) and pH in PC1 (Fig. 4 and Table 1). Surface water ANC and $\mathrm{pH}$ are standard indicators used in acidification studies, as both are strongly indicative of biological recovery (Hutchinson et al., 1989; Lien et al., 1996). In addition, 
Table 1. Drivers (time-series inputs and processes) incorporated into the three simulation scenarios: Base, Redox and DOC (see Fig. 2 for model linkages).

\begin{tabular}{|c|c|c|c|c|}
\hline \multicolumn{2}{|r|}{ Simulation drivers: change direction [simulation model] } & \multicolumn{3}{|c|}{ Scenario } \\
\hline & & Base & Redox & DOC \\
\hline A & $\begin{array}{l}\text { Future sulphate deposition under NOX3P emission scenario: } \sim 40 \% \text { decrease by } \\
2020 \text { from } 1989 \text { base [ADOM] }\end{array}$ & $x$ & $x$ & $x$ \\
\hline $\mathrm{B}$ & $\begin{array}{l}\text { Future climate under } \mathrm{A} 2 \text { emissions scenario: } \sim 5^{\circ} \mathrm{C} \text { increase in temperature and } 5 \% \\
\text { increase in precipitation between } 2000 \text { and } 2100 \text { [HadCM3, SDSM] }\end{array}$ & $x$ & $x$ & $x$ \\
\hline $\mathrm{C}$ & $\begin{array}{l}\text { Runoff under simulated precipitation and temperature: } \sim 10 \% \text { decrease between } \\
2000 \text { and } 2100[\mathrm{HBV}]\end{array}$ & $x$ & $x$ & $x$ \\
\hline $\mathrm{D}$ & $\begin{array}{l}\text { Wetland reduction-oxidation processes: sulphur oxidation during low flow summer } \\
\text { periods [MAGIC] }\end{array}$ & & $x$ & $x$ \\
\hline $\mathrm{E}$ & $\begin{array}{l}\text { Dissolved organic carbon (DOC) under the simulated precipitation, temperature and } \\
\text { HBV moisture characteristics: } \sim 20 \% \text { increase between } 2000 \text { and } 2100 \text { [INCA-C] }\end{array}$ & & & $x$ \\
\hline
\end{tabular}

ADOM: Acid Deposition and Oxidant Model, HadCM3: Hadley Centre General Circulation Model, HBV: Hydrologiska Byråns Vattenbalansavdelning, INCA-C: Integrated Catchments model for Carbon, MAGIC: Model of Acidification of Groundwater in Catchments, and SDSM: Statistical Downscaling Model.

Table 2. Simulated surface water concentrations in PC1 outflow during selected periods (five-year mean centred on the reporting year) for the base, redox and DOC simulation scenarios under future climate change and sulphate emission reductions.

\begin{tabular}{llrrrrr}
\hline Parameter & Scenario & \multicolumn{5}{c}{ Surface water chemistry } \\
$\left(\right.$ unit: $\left.\mu \mathrm{mol}_{c} \mathrm{~L}^{-1}\right)$ & & 2000 & 2020 & 2040 & 2060 & 2080 \\
\hline Acid neutralising capacity & Base & -2.62 & 18.46 & 25.17 & 27.79 & 27.94 \\
pH & Base & 4.34 & 4.47 & 4.53 & 4.56 & 4.56 \\
Sulphate & Base & 116.83 & 66.32 & 58.31 & 59.68 & 62.90 \\
Base cations & Base & 127.40 & 98.16 & 97.07 & 100.79 & 105.51 \\
Acid neutralising capacity & Redox & -0.82 & 23.27 & 8.07 & 24.07 & 8.40 \\
pH & Redox & 4.35 & 4.51 & 4.43 & 4.52 & 4.41 \\
Sulphate & Redox & 110.52 & 55.40 & 72.31 & 47.61 & 68.05 \\
Base cations & Redox & 122.85 & 92.07 & 93.58 & 84.99 & 90.93 \\
pH & DOC & 4.39 & 4.48 & 4.49 & 4.59 & 4.45 \\
\hline
\end{tabular}

ANC is the most widely used chemical criterion in critical load calculations for surface waters (Henriksen et al., 1995).

Future climate variability (excluding redox events) and deposition forecasts from ADOM were used to simulated surface water chemistry for PC1 for the period 2000-2100 under the base scenario. Sulphate deposition is forecasted to decrease until 2020 (approximately 40\% from 1989). In contrast, mean temperature is predicted to increase from 5.4 to $10.3^{\circ} \mathrm{C}$ and precipitation to increase by $5 \%$ between 2000 and 2100 (Fig. 3). The proposed deposition reductions showed significant recovery in stream ANC and $\mathrm{pH}$ between 2000 and 2100 (Fig. 4 and Table 2) with ANC increasing from $<0 \mu \mathrm{mol}_{c} \mathrm{~L}^{-1}$ to $>25 \mu \mathrm{mol}_{c} \mathrm{~L}^{-1}$ and $\mathrm{pH}$ increasing by $>0.2 \mathrm{pH}$ units. The direct influence of climate (temperature, precipitation and runoff) had little impact on chemical recovery. To some extent the variable pattern in simulated surface water chemistry is driven by the inter-annual variation in pre- cipitation and runoff; however, as $\mathrm{S}$ emissions decrease the inter-annual variation was less pronounced (Fig. 4).

The recovery from acidification is primarily driven by reduced depositions rather than the direct influence of climate. Simulated surface water chemistry showed a significant recovery potential under the current deposition reduction; by 2100 stream concentration levels recovered to values predicted for the early 1960s. More importantly, under the base scenario recovery extends well beyond 2020 when the deposition reduction is fully implemented (Fig. 4 and Table 2). The continued recovery is primarily driven by the continued improvement (increase) in percent soil base saturation (from 11.5 to $14.5 \%$; not shown). The A2 emission scenarios of the IPCC employed in the current study indicates significant climate change in the coming decades (Fig. 3); nonetheless, model simulations show little influence from climate. Wright et al. (2006) have recently noted the limitations in current 

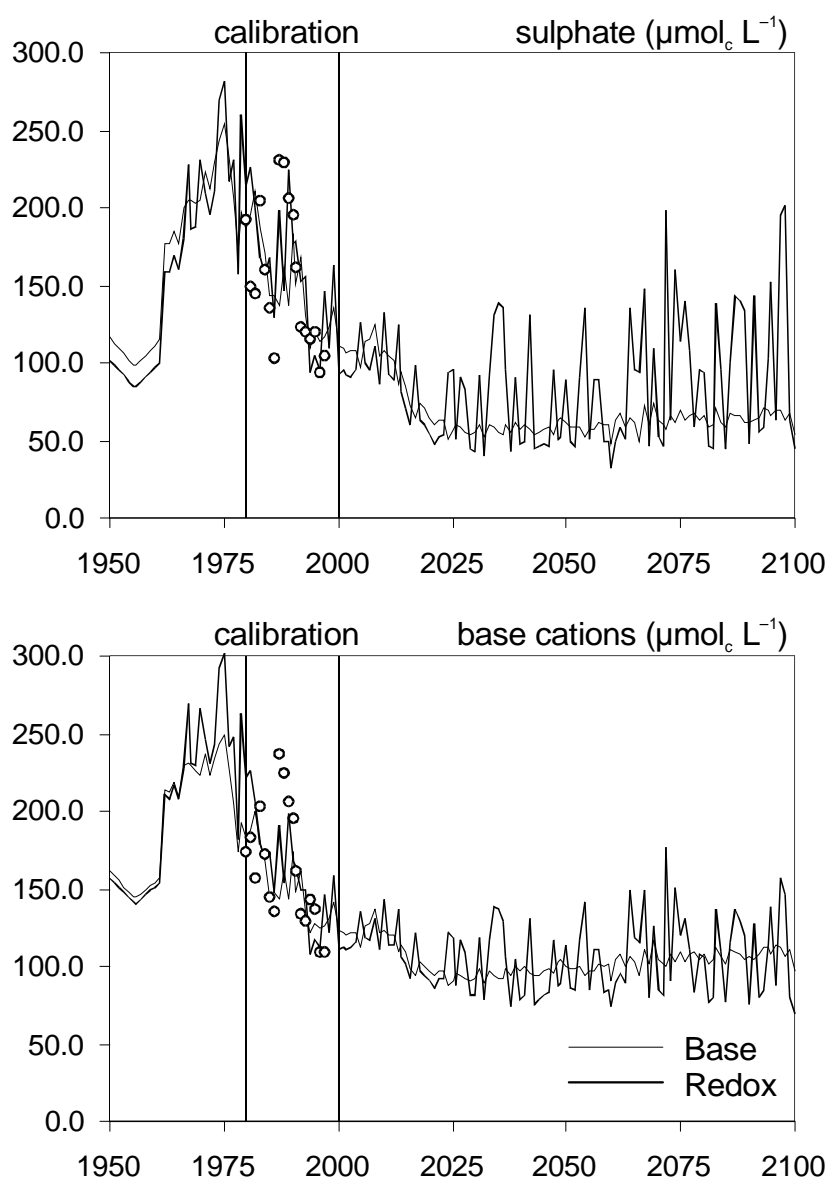

Fig. 5. Simulated sulphate $\left(\mu \mathrm{mol}_{C} \mathrm{~L}^{-1}\right.$ : upper panel) and base cation (calcium + magnesium + sodium + potassium, $\mu \operatorname{mol}_{c} \mathrm{~L}^{-1}$ : lower panel) under the base scenario (thin line) and redox scenario (black line) for the period 1960-2100. The calibration period (1980-2000) and the observed data (open circles) are also shown.

modelling structures to represent climate-induced changes. Climate-induced changes in processes are generally not incorporated in current versions of acidification models. This is largely due to the lack of knowledge on the detailed cause and mechanisms linking changes in climate to changes in soil and water chemistry (Wright et al., 2006).

\subsection{Influence of redox processes on recovery}

There are a number of factors that can influence the extent of chemical recovery from acidification (Beier et al., 2003; Evans, 2005; Larssen, 2005; Skjelkvåle et al., 2005; Aherne et al., 2004, 2006). The incorporation of climate-induced redox events strongly influences the forecasted surface water chemistry at PC1 (Fig. 4 and Table 2). Stream ANC and $\mathrm{pH}$ show very large inter-annual variations under the redox scenario; more importantly, the forecasted recovery potential is very much reduced. To some extent, this pattern is driven by the inter-annual variation in precipitation

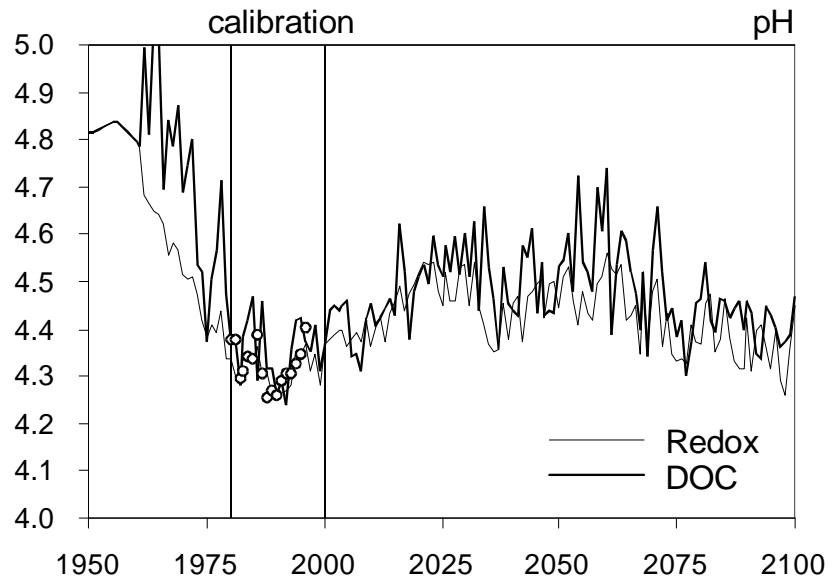

Fig. 6. Simulated $\mathrm{pH}$ under the redox scenario (thin line) and DOC scenario (thick line) for the period 1960-2100. The calibration period (1980-2000) and the observed data (open circles) are also shown.

(Fig. 3) and deposition inputs; however, climate-induced redox events strongly influence the forecasted catchment outflow. The future runoff scenario includes significant periods where runoff is $<5 \mathrm{~cm} \mathrm{mo}^{-1}$, the oxidation threshold. Recovery (increases) in ANC owing to deposition reductions is clearly offset by large acid effluxes from the redox events. By $2100, \mathrm{ANC}$ is predicted to show large variations ranging between 10 and $-30 \mu \mathrm{mol}_{c} \mathrm{~L}^{-1}$. Similarly, predicated $\mathrm{pH}$ in 2100 is lower than the value simulated for $2000(<\mathrm{pH} 4.3$ : Fig. 4 and Table 2). Despite emission reductions, the redox scenario paints a bleak picture of reacidification at $\mathrm{PC} 1$ to levels commensurate with those of the late 1970s (Fig. 4). In the current study, the redox events are driven by the A2 emission scenario of the IPCC, which may be viewed as somewhat pessimistic as it is a high emissions scenario. Nonetheless, drought-induced acid export from wetlands has the potential to delay (or reverse) recovery of surface waters from acidification in south-central Ontario (Aherne et al., 2006).

The simulated drought events have a considerable impact on outflow chemistry, resulting in increased $\mathrm{SO}_{4}^{2-}$ and base cations and decreased ANC concentrations (Figs. 4 and 5). The largest effect is on simulated $\mathrm{SO}_{4}^{2-}$ surface water concentrations (Fig. 5 and Table 2). There are significant differences between the base and redox scenarios. The redox scenario exhibits repeated export of $\mathrm{SO}_{4}^{2-}$ during drought (or low-flow) years when discharge falls below the oxidation threshold $\left(5 \mathrm{~cm} \mathrm{mo}^{-1}\right)$. Under the redox scenario, discharge fell below the oxidation threshold during many of the years, but only during years with extended periods of drought was $\mathrm{SO}_{4}^{2-}$ export observed. In total, there were 45 event-years where $\mathrm{SO}_{4}^{2-}$ export was observed during the period 20002100. The significant decrease in simulated ANC (Fig. 4) was due to the increased flux of $\mathrm{SO}_{4}^{2-}$ (Fig. 5); however, the impact on ANC was somewhat decreased owing to the increased flux of base cations (Fig. 5). 
The frequency of drought (or low-flow) events has a significant influence on predicted water quality. In the current study, the runoff scenario was generated using HBV in conjunction with downscaled temperature and precipitation derived from HadCM3 under the A2 emission scenario of the IPCC. During the 100 year simulation period (2000-2100) there are approximately 40 years with low-flow periods. The intensity and frequency of these events increased during the latter years of the simulation (from 2030) driving the reacidification at $\mathrm{PC} 1$.

\subsection{Influence of dissolved organic carbon on recovery}

Increases in DOC have been observed across Europe and eastern North America during the past 10-20 years (Stoddard et al., 2003; Evens et al., 2005). It has been suggested that factors related to climate change, acid deposition and changes in land use may be responsible for these increases (Evans et al., 2006; Holmberg et al., 2006; Roulet and Moore, 2006; Vuorenmaa et al., 2006). Increasing trends in temperature and decreasing rates of $\mathrm{S}$ depositions have both been implicated as potential drivers of these observed increases in DOC concentrations. In the current study, the INCA-C model predicted that DOC concentrations will increase (Fig. 3). The simulated increase in DOC did not result in further decreases in $\mathrm{pH}$ (Fig. 6) beyond the redox scenario (Fig. 6 and Table 2); instead pH showed greater variability throughout the simulation under the DOC scenario.

The predicted (significant) increasing trend in DOC concentrations at $\mathrm{PC} 1$ is not surprising given the somewhat ubiquitous increasing trends observed across north America and Europe (Freeman et al., 2001; Stoddard et al., 2003; Worrall et al., 2004; Evans et al., 2005; Skjelkvåle et al., 2005; Vuorenmaa et al., 2006). In the current study, the predicted increase in DOC is primarily driven by increasing temperature (Fig. 3). However, it is important to note that the INCA-C predictions were based on climate alone and did not incorporate the effects of decreasing $\mathrm{S}$ deposition rates on DOC. Although empirical studies have shown a correlation between decreasing $\mathrm{S}$ deposition and increasing DOC, no widely accepted mechanism currently exists; consequently initial attempts to include $\mathrm{S}$ deposition as a driver in INCA$\mathrm{C}$ have not been successful.

Wright et al. (2006) suggested that the modelling of recovery from acidification should take into account climateinduced changes in organic acids. Ultimately this requires that the appropriate processes are incorporated into existing hydrochemical effects models. In the current study, INCA$\mathrm{C}$ was used to provide DOC time-series input to MAGIC. The framework did not allow for feedback between models; accordingly, only surface water DOC concentrations were linked to MAGIC. As such, DOC only influences the acid status $(\mathrm{pH})$ of the surface water compartment under the current model structure in MAGIC. Nonetheless, it represents an exploratory assessment of the potential influence of chang- ing surface water DOC concentrations on the acidity of PC1. The predicted increase in DOC resulted in greater variability in simulated $\mathrm{pH}$ with little, if any, further decrease in $\mathrm{pH}$ beyond the redox scenario.

\section{Conclusions}

Clearly, greater consideration of climatic effects (and climate variability) on biogeochemical cycles should be considered when predicting the recovery of acidified surface waters (Forsius et al., 1997; Evans, 2005; Aherne et al., 2006; Wright et al., 2006). The current study clearly shows the importance of future climate variability; specifically low-flow (or drought) events, on the recovery of Plastic Lake subcatchment 1 from acidification. In south-central Ontario, the future recovery of surface waters under reduced depositions may be delayed (or reversed) by drought-induced $\mathrm{SO}_{4}^{2-}$ export from wetlands owing to redox processes. By 2100 the $\mathrm{pH}$ of $\mathrm{PC} 1$ is predicted to be $<5.0$ and $\mathrm{ANC}$ is predicted to range between -40 and $+20 \mu \operatorname{mol}_{c} \mathrm{~L}^{-1}$. As echoed by many recent studies (Aherne et al., 2006; Wright et al., 2006; Posch et al., 2008), hydrochemical models and model frameworks, need to incorporate the drivers and mechanisms that affect the key biogeochemical processes (at appropriate timescales) to reliably predict the impacts of climate change. This study presents the first steps towards a robust framework for reliable prediction of chemical recovery from acidification at PC1. Importantly, the approach incorporated a climate scenario downscaled from a GCM and a high-resolution scenario for catchment discharge. Future studies should include strict acceptance criteria for downscaled precipitation (limit ensembles of downscaled climate to those that meet specified performance criteria). This should be similarly applied to hydrological simulations. Additional drivers, such as $\mathrm{S}$ deposition, need to be incorporated into DOC models. Ultimately, greater communication (or feedback) is required between the individual linked process-oriented models. Alternatively, climate change mechanisms that affect key biogeochemical processes need to be incorporated directly into process-oriented models (one model versus many linked models).

Acknowledgements. This research was undertaken, in part, thanks to funding from the Canada Research Chairs Program and an NSERC Discovery grant. M. N. Futter was funded by the Eurolimpacs project (GOCE-CT-2003-505540) and an NSERC/Suncor IPS Fellowship.

Edited by: P. Dillon and R. F. Wright 


\section{References}

Aherne, J., Larssen, T., Dillon, P. J., and Cosby, B. J.: Effects of climate events on elemental fluxes from forested catchments in Ontario, Canada: modelling drought-induced redox processes, Water Air Soil Pollut. Focus, 4, 37-48, 2004.

Aherne, J., Larssen, T., Cosby, B. J., and Dillon, P. J.: Climate variability and forecasting surface water recovery from acidification: modelling drought-induced sulphate release from wetlands, Sci. Total Environ., 365, 186-199, 2006.

Beier, C., Moldan, F., and Wright, R. F.: Terrestrial ecosystem recovery - modelling the effects of reduced acidic inputs and increased inputs of sea salts induced by global change, Ambio, 32, 275-282, 2003.

Bergström, S.: Development and Application of a Conceptual Runoff Model for Scandinavian Catchments, Swedish Meteorological and Hydrological Institute, Norrköping, 134 pp., 1976.

Cosby, B. J., Hornberger, G. M., Galloway, J. N., and Wright, R. F.: Modeling the effects of acid deposition: assessment of a lumped parameter model of soil water and streamwater chemistry, Water Resour. Res., 21, 51-63, 1985.

Cosby, B. J., Ferrier, R. C., Jenkins, A., and Wright, R. F.: Modelling the effects of acid deposition: refinements, adjustments and inclusion of nitrogen dynamics in the MAGIC model, Hydrol. Earth Syst. Sci., 5, 499-517, 2001,

http://www.hydrol-earth-syst-sci.net/5/499/2001/.

Devito, K. J. and Hill, A. R.: Sulphate mobilization and pore water chemistry in relation to groundwater hydrology and summer drought in two conifer swamps on the Canadian shield, Water Air Soil Pollut., 113, 97-114, 1999.

Dillon, P. J. and LaZerte, B. D.: Response of the Plastic Lake catchment, Ontario, to reduced sulphur deposition, Environ. Pollut., 77, 211-217, 1992.

Dillon, P. J., Reid, R. A., and de Grosbois, E.: The rate of acidification of aquatic ecosystems in Ontario, Canada, Nature, 329, 45-48, 1987.

Dillon, P. J., Lusis, M., Reid, R. A., and Yap, D.: Ten-year trends in sulphate, nitrate and hydrogen deposition in central Ontario, Atmos. Environ., 22, 901-905, 1988.

Dillon, P. J., Molot, L. A., and Futter, M.: The effect of El Niño-related drought on the recovery of acidified lakes, Environ. Monit. Assess., 46, 105-111, 1997.

Eimers, M. C. and Dillon, P. J.: Climate effects on sulphate flux from forested catchments in south-central Ontario, Biogeochemistry, 61, 337-355, 2002.

Eimers, M. C., Dillon, P. J., and Schiff, S. L.: Sulphate flux from an upland forested catchment in south-central Ontario, Canada, Water Air Soil Pollut., 152, 3-21, 2004.

Evans, C. D.: Modeling the effects of climate change on an acidic upland stream, Biogeochemistry, 74, 21-46, 2005.

Evans, C. D., Monteith, D. T., and Cooper, D. M.: Long-term increases in surface water dissolved organic carbon: Observations, possible causes and environmental impacts, Environ. Pollut., 137, 55-71, 2005.

Evans, C. D., Chapman, P. J., Clark, J. M., Monteith, D. T., and Cresser, M. S.: Alternative explanations for rising dissolved organic carbon export from organic soils, Global Change Biol., 12, 2044-2053, 2006.

Forsius, M., Johansson, M., Posch, M., Holmberg, M., Kämäri, J., Lepistö, A., Roos, J., Syri, S., and Starr, M.: Modelling the ef- fects of climate change, acidic deposition and forest harvesting on the biogeochemistry of a boreal forested catchment in Finland, Boreal Environ. Res., 2, 129-143, 1997.

Freeman, C., Evans, C. D., Monteith, D. T., Reynolds, B., and Fenner, N.: Export of organic carbon from peat soil, Nature, 412, 785-785, 2001.

Freeman, C., Fenner, N., Ostle, N. J., Kang, H., Dowrick, D. J., Reynolds, B., Lock, M. A., Sleep, D., Hughes, S., and Hudson, J.: Export of dissolved organic carbon from peatlands under elevated carbon dioxide levels, Nature, 430, 195-198, 2004.

Futter, M. N., Butterfield, D., Cosby, B. J., Dillon, P. J., Wade, A. J., and Whitehead, P. G.: Modeling the mechanisms that control in-stream dissolved organic carbon dynamics in upland and forested catchments, Water Resour. Res., 43, W02424, doi:10.1029/2006WR004960, 2007.

Hejzlar, J., Dubrovský, M., Buchtele, J., and Ružička, M.: The apparent and potential effects of climate change on the inferred concentration of dissolved organic matter on a temperate stream (The Mãlse River, South Bohemia), Sci. Total Environ., 310, 143-152, 2003.

Henriksen, A., Posch, M., Hultberg, H., and Lien, L.: Critical loads of acidity for surface waters - can the ANClimit be considered variable?, Water Air Soil Pollut., 85, 2419-2424, 1995.

Holmberg, M., Forsius, M., Starr, M., and Huttunen, M.: An application of artificial neural net-works to carbon, nitrogen and phosphorus concentrations in three boreal streams and impacts of climate change, Ecol. Model., 195, 51-60, 2006.

Hutchinson, N. J., Holtze, K. E., Munro, J. R., and Pawson, T. W.: Modifying effects of life stage, ionic strength and post-exposure mortality on lethality of $\mathrm{H}+$ and $\mathrm{Al}$ to lake trout and brook trout, Aquat. Toxicol., 15, 1-26, 1989.

Janssen, P. H. M. and Heuberger, P. S. C.: Calibration of processoriented models, Ecol. Model., 83, 55-66, 1995.

Jeffries, D. S., Clair, T. A., Dillon, P. J., Papineau, M., and Stainton, M. P.: Trends in surface water acidification at ecological monitoring sites in southeastern Canada (1981-1991), Water Air Soil Pollut., 85, 577-582, 1995.

Jeffries, D. S., Clair, T. C., Couture, S., Dillon, P. J., Dupont, J., Keller, W., McNicol, D. K., Turner, M. A., Vet, R., and Weeber, R.: Assessing the recovery of lakes in southeastern Canada from the effects of acid deposition, Ambio, 32, 176-182, 2003.

Kaste, Ø., Wright, R. F., Barkved, L. J., Bjerkeng, B., EngenSkaugen, T., Magnusson, J., and Sælthun, N. R.: Linked models to assess the impacts of climate change on nitrogen in a Norwegian river basin and fjord system, Sci. Total Environ., 365, 200-222, 2006.

Kalnay, E., Kanamitsu, M., Kistler, R., Collins, W., Deaven, D., Gandin, L., Iredell, M., Saha, S., White, G., Woolen, J., Zhu, Y, Chelliah, M., Ebisuzaki, W., Higgins, W., Janowiak, J., Mo, K. C., Ropelewski, C., Wang, J., Leetma, A., Reynolds, R., Jenne, R., and Joseph, D.: The NCEP/NCAR 40-year reanalysis project, Bull. Am. Meteor. Soc., 77, 437-471, 1996.

Kaminski, J. W.: Emissions-Scenario Simulations of New Provincial SO2 Reduction Targets using the Acid Deposition and Oxidant Model, Atmospheric Research and Modelling Consultants, Toronto, 23 pp., 2002.

Kirkwood, D. E. and Nesbitt, H. W.: Formation and evolution of soils from an acidified watershed: Plastic Lake, Ontario, Canada, Geochim. Cosmochim. Acta, 55, 1295-1308, 1991. 
Larssen, T.: Model prognoses for future acidification recovery of surface waters in Norway using long-term monitoring data, Environ. Sci. Technol., 39, 7970-7979, 2005.

Laudon, H., Dillon, P. J., Eimers, M. C., Semkin, R. G., and Jeffries, D. S.: Climate induced episodic acidification of streams in Central Ontario, Environ. Sci. Technol., 38, 6009-6015, 2004.

LaZerte, B. D.: The impact of drought and acidification on the chemical exports from a minerotrophic conifer swamp, Biogeochemistry, 18, 153-175, 1993.

Lien, L., Raddum, G. G., Fjellheim, A., and Henriksen, A.: A critical limit for acid neutralizing capacity in Norwegian surface waters, based on new analyses of fish and invertebrate responses, Sci. Total Environ., 177, 173-193, 1996.

Locke, B. A. and Scott, L. D.: Studies of lakes and watersheds in Muskoka-Haliburton, Ontario: Methodology (1976-1985), Data Report DR 86/4, Dorset Research Centre, Ontario Ministry of the Environment, Dorset, Ontario, Canada, 1986.

Lozano, F.: Physical and chemical properties of the soils at the southern biogeochemistry study site, Report BGC-018, Dorset Research Centre, Ontario Ministry of the Environment, Dorset, Ontario, Canada, 1987.

Lozano, F. and Parton, W. J.: Forest cover characteristics of the Harp \#4 and Plastic \#1 sub-catchments at the southern biogeochemical study site, Report BGC-006, Dorset Research Centre, Ontario Ministry of the Environment, Dorset, Ontario, Canada, 1987.

McNicol, D. K., Mallory, M. L., Laberge, C., and Cluis, D. A.: Recent temporal patterns in the chemistry of small acid sensitive lakes in central Ontario, Canada, Water Air Soil Pollut., 105, 343-351, 1998

Nakićenović, N., Alcamo, J., Davis, G., De Vries, B., Fenhann, J., Gaffin, S., Gregory, K., Grübler, A., Jung, T. Y., Kram, T., La Rovere, E. L., Michaelis, L., Mori, S., Morita, T., Pepper, W., Pitcher, H., Price, L., Raihi, K., Roehrl, A., Rogner, H.-H., Sankovski, A., Schlesinger, M., Shukla, P., Smith, S., Swart, R., Van Rooijen, S., Victor, N., and Dadi, Z.: Emissions Scenarios, A Special Report of Working Group III of the Intergovernmental Panel on Climate Change, Cambridge University Press, 599 pp., 2000.

Nash, J. E. and Sutcliffe, J. V.: River flow forecasting through conceptual models: Part 1. A discussion of principles, J. Hydrol., 10, 282-290, 1970.

Neary, A. J. and Gizyn, W. I.: Throughfall and stemflow under deciduous and coniferous forest canopies in south-central Ontario, Can. J. For. Res., 24, 1089-1110, 1994.

OME: Handbook of analytical methods for environmental samples, Technical Report, Ontario Ministry of the Environment, Rexdale, Ontario, Canada, 246 pp., 1983.

Posch, M., Aherne, J., Forsius, M., Fronzek, S., and Veijalainen, N.: Modelling the impacts of European emission and climate change scenarios on acid-sensitive catchments in Finland, Hydrol. Earth Syst. Sci., 12, this special issue, 2008.
Roulet, N. and Moore, T. R.: Browning the waters, Nature, 444, 283-284, 2006.

Skjelkvåle, B. L., Evans, C., Larssen, T., Hindar, A., and Raddum, G. G.: Recovery from acidification in European surface waters: a view to the future, Ambio, 32, 170-175, 2003.

Skjelkvåle, B. L., Stoddard, J. L., Jeffers, J. N. R., Tørseth, K., Høgåsen, T., Bowman, J., Mannio, J., Monteith, D., Mosello, R., Rogora, M., Rzychon, D., Veselý, J., Wieting, J., Wilander, A., and Worsztynowicz, A.: Regional scale evidence for improvements in surface water chemistry 1990-2001, Environ. Pollut., 137, 165-176, 2005.

Stoddard, J. L., Jeffries, D. S., Lükewille, A., Clair, T. A., Dillon, P. J., Driscoll, C. T., Forsius, M., Johannessen, M., Kahl, J. S., Kellogg, J. H., Kemp, A., Mannio, J., Monteith, D. T., Murdoch, P. S., Patrick, S., Rebsdorf, A., Skjelkvåle, B. L., Stainton, M. P., Traaen, T., Van Dam, H., Webster, K. E., Wieting, J., and Wilander, A.: Regional trends in aquatic recovery from acidification in North America and Europe, Nature, 401, 575-578, 1999.

Stoddard, J. L., Karl, J. S., Deviney, F. A., DeWalle, D. R., Driscoll, C. T., Herlihy, A. T., Kellogg, J. H., Murdoch, P. S., Webb, J. R., and Webster, K. E.: Response of Surface Water Chemistry to the Clean Air Act Amendments of 1990, Report EPA 620/R-03/001, United States Environmental Protection Agency, North Carolina, 2003, 78 pp., 2003.

Sælthun, N. R.: The "Nordic" HBV model, Description and documentation of the model version developed for the project Climate Change and Energy Production, NVE publication, Oslo, Norwegian Water Resources and Energy Administration, 82-410-02734, 26 pp., 1996.

Vuorenmaa, J., Forsius, M., and Mannio, J.: Increasing trends of total organic carbon concentrations in small forest lakes in Finland from 1987 to 2003, Sci. Total Environ., 365, 47-65, 2006.

Watmough, S. A. and Dillon, P. J.: Major fluxes from a coniferous catchment in central Ontario, 1983-1999, Biogeochemistry, 67, 369-398, 2004.

Wilby, R. L., Dawson, C. W., and Barrow, E. M.: SDSM - a decision support tool for the assessment of regional climate change impacts, Environ. Modell. Software, 17, 145-157, 2002.

Worrall, F., Harriman, R., Evans, C. D., Watts, C. D., Adamson, J., Neal, C., Tipping, E., Burt, T., Grieve, I., Monteith, D., Naden, P. M., Nisbet, T., Reynolds, B., and Stevens, P.: Trends in dissolved organic carbon in UK in rivers and lakes, Biogeochemistry, 70, 369-402, 2004.

Wright, R. F., Aherne, J., Bishop, K., Camarero, L., Cosby, B. J., Erlandsson, M., Evans, C. D., Forsius, M., Hardekopf, D., Helliwell, R., Hruska, J., Jenkins, A., Moldan, F., Posch, M., and Rogora, M.: Modelling the effect of climate change on recovery of acidified freshwaters: relative sensitivity of individual processes in the MAGIC model, Sci. Total Environ., 365, 154-166, 2006.

WxPrime: Emissions-Scenario Simulations of Potential Nitrogen Emission Reductions Using the Acid Deposition and Oxidant Model (ADOM), WxPrime Corporation, Toronto, 51 pp., 2004. 